\title{
Seasonal distribution of DMSP among seston, dissolved matter and zooplankton along a transect in the Long Island Sound estuary*
}

\author{
Kam W. Tang**, Daniel R. Rogers, Hans G. Dam, Pieter T. Visscher \\ Department of Marine Sciences, University of Connecticut, 1084 Shennecossett Road, Groton, Connecticut 06340, USA
}

\begin{abstract}
We studied the seasonal distribution of dimethylsulfoniopropionate (DMSP) among seston, dissolved matter and zooplankton along a transect in eastern Long Island Sound. The seston DMSP concentration (1 to $52 \mathrm{nM}$ ) was comparable to that reported for some estuaries. Most of the seston DMSP was derived from particles $<10 \mu \mathrm{m}$. Seston DMSP concentration did not correlate with water temperature or salinity. Most of the seston DMSP appeared to have originated from phytoplankton. Both dissolved DMSP and dimethyl sulfide (DMS) concentrations remained low $(<3 \mathrm{nM})$ and were highly correlated to each other $(\mathrm{r}=0.83, \mathrm{p}<0.01)$. Assuming a steady state condition, the conversion efficiency from dissolved DMSP to DMS was estimated to be $76 \%$. On the other hand, seston DMSP concentration did not correlate with dissolved DMSP, implying that the accumulation of seston DMSP and dissolved DMSP were uncoupled. Four types of copepods plus several other types of zooplankters contained DMSP. The copepod Temora longicornis contained $2.8 \mathrm{nmol}$ DMSP per individual, the highest among the zooplankters. For most of the year, zooplankton were a negligible component of particulate DMSP in the water column. However, in months when T. longicornis appeared in high abundance, zooplankton represented 14 to $72 \%$ of the total particulate DMSP. Estimated copepod body DMSP concentrations were orders of magnitude higher than seston and dissolved DMSP concentrations; thus, copepod bodies represent a sparse, but highly concentrated source of particulate DMSP.
\end{abstract}

KEY WORDS: Dimethylsulfoniopropionate $\cdot$ Dimethyl sulfide $\cdot$ Copepods $\cdot$ Planktonic larvae $\cdot$ Cladocerans $\cdot$ Microzooplankton $\cdot$ Detritus

\section{INTRODUCTION}

The oceans can affect the global climate through the production of atmospherically active gases such as dimethyl sulfide (DMS) (Charlson et al. 1987). DMS is a breakdown product of dimethylsulfoniopropionate (DMSP), one of several osmolytes synthesized by phytoplankton (Keller \& Korjeff-Bellows 1996, Kirst 1996). Oceanic DMS is the major biogenic sulfur

\footnotetext{
*This paper is dedicated to the memory of Maureen D. Keller

${ }^{* *}$ Present address: Danish Institute for Fisheries Research, Kavelergarden 6, Charlottenlund 2920, Denmark

E-mail: kta@dfu.min.dk
}

species for sea-air exchange (Lovelock et al. 1972, Nguyen et al. 1978, 1983, Andreae \& Raemdonck 1983), and it contributes to cloud formation in the atmosphere (Charlson et al. 1987, Andreae 1990). Although DMSP produced by phytoplankton is the main source of oceanic DMS, the transformation of DMSP to DMS is a complex process mediated by various ecological processes in the water column (Fig. 1). For instance, bacteria and microzooplankton may consume DMSP and DMS (Visscher et al. 1992, Visscher \& Taylor 1993, 1994, Wolfe et al. 1994, Kiene et al. 1998); zooplankton may channel DMSP from phytoplankton to zooplankton biomass, fecal material or dissolved DMSP through grazing and osmoregulation (Dacey \& Wakeham 1986, Kwint et al. 1996, Tang et al. 1999, 


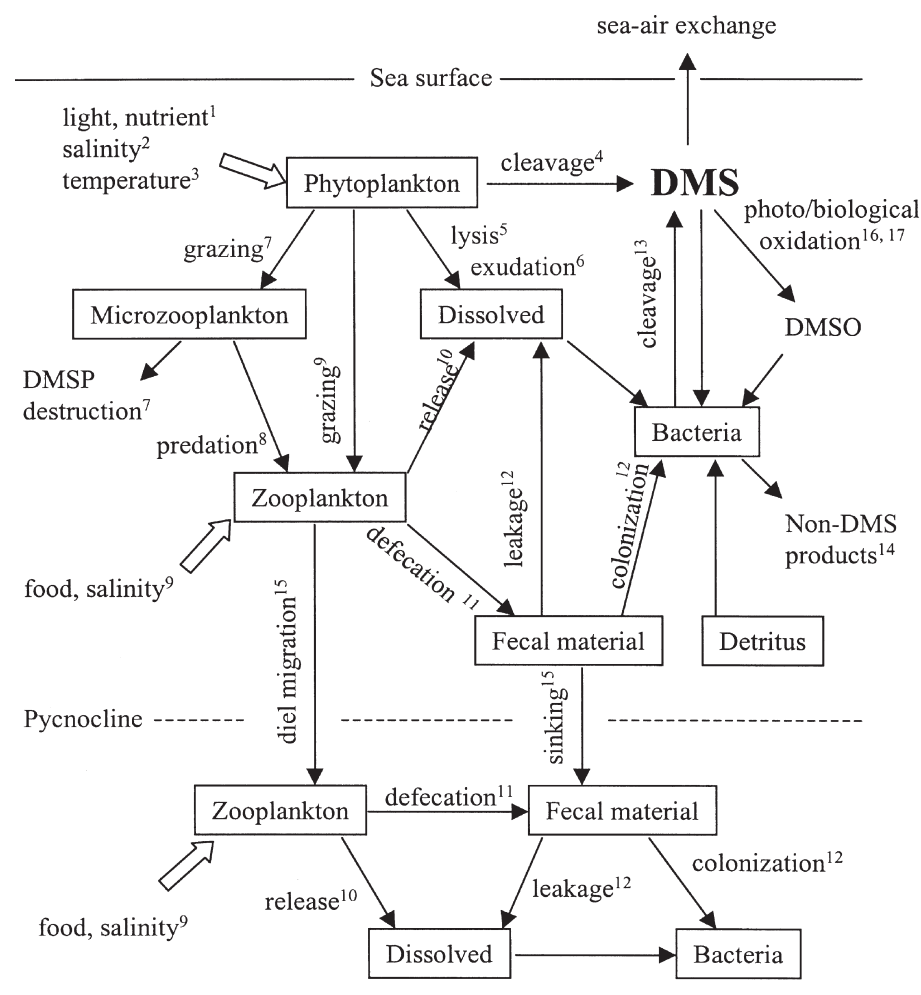

Fig. 1. Schematic diagram of DMSP dynamics in pelagic food web. Each box represents a DMSP pool. Open arrows represent known factors that affect DMSP pools, thin arrows fluxes between pools. Following references are only examples (more complete list of references can be found in the studies cited): 1: Keller \& Korjeff-Bellows (1996); 2: Kirst (1996); 3: Karsten et al. (1996); 4: Stefels \& van Boekel (1993); 5: Bratbak et al. (1995); 6: Laroche et al. (1999); 7: Wolfe et al. (1994); 8: Levasseur et al. (1996); 9: Tang et al. (1999); 10: Tang et al. (2000); 11: Kwint et al. (1996); 12: Tang (2000b); 13: Ledyard \& Dacey (1994); 14: Visscher \& Taylor (1994); 15: Tang (2000a); 16: Brimblecombe \& Shooter (1986); 17: Zeyer et al. (1987)
Ikeda 1992). As a result, the 'particulate matter' described in the literature is in fact predominantly seston, and the contribution of zooplankton to the total DMSP in particulate matter is unknown. Based on separate data sets, Tang et al. (1999) estimated that copepods at times account for up to $77 \%$ of the total particulate DMSP in Long Island Sound. These authors showed that copepods exhibit large inter-specific variation in DMSP content; thus, the contribution of zooplankton to the total DMSP concentration may be expected to change when the zooplankton community structure varies between seasons.

We conducted a year-long study of the distribution of DMSP among seston, dissolved matter and zooplankton along a transect in an estuary in eastern Long Island Sound. In this study we asked: (1) How does DMSP distribution in each pool change seasonally? (2) Are the amounts of DMSP among different pools correlated to each other? (3) How important is zooplankton as a component of the DMSP budget in the water column? In this study, we collected zooplankton separately from water samples, and regarded zooplankton as part of the total particulate matter. Thus, to avoid confusion, we labeled the particles in water samples as 'seston', which is often described as 'particulate matter' in the literature. Our results show that (1) seston DMSP was mostly derived from phytoplankton, (2) the accumulation of dissolved DMSP and DMS were tightly coupled, and (3) in certain months, zooplankton were a more important source of DMSP than seston.
2000, Tang 2000a). Global measurements have shown poor correlation between DMS and primary production parameters (e.g. seston DMSP, chlorophyll, dissolved nutrients) (Kettle et al. 1999), further confirming that factors other than primary producers play a role in oceanic DMSP production and consumption. Unfortunately, biological components other than phytoplankton or seston have often been neglected in most DMSP field studies (Turner et al. 1988, Iverson et al. 1989, Belviso et al. 1993, Malin et al. 1993, Bates et al. 1994, Townsend \& Keller 1996, Dacey et al. 1998). In most DMSP field studies, water samples were collected with conventional water-sampling devices and the seston was concentrated on filter papers (e.g. Bates et al. 1994, Cantin et al. 1996, Townsend \& Keller 1996, Dacey et al. 1998). This sampling technique neither differentiates phytoplankton, microzooplankton and detritus among the seston, nor does it appropriately collect actively swimming zooplankters (Omori \&

\section{MATERIALS AND METHODS}

Sampling sites. Three sampling stations were located in eastern Long Island Sound (Fig. 2). Between December 1998 and January 2000, each station was visited 9 times. Each site visit consisted of 2 consecutive sampling days. On Day 1, surface water was collected for analysis of seston DMSP $\left(\mathrm{DMSP}_{\mathrm{s}}\right)$, dissolved DMSP $\left(\right.$ DMSP $\left._{\mathrm{d}}\right)$ and DMS content. On Day 2, surface water was collected for chlorophyll and seston carbon determinations. Zooplankton tows were done on Day 2 for determination of zooplankton abundance and DMSP content $\left(\mathrm{DMSP}_{\mathrm{z}}\right)$. Handling of water and zooplankton samples is explained in detail in the following sections. Surface water temperature and salinity were measured with a submersible thermometer and a hand refractometer, respectively.

$\mathbf{D M S P}_{\mathbf{s}}, \mathbf{D M S P}_{\mathbf{d}}$ and DMS. One-liter polycarbonate bottles were filled with surface seawater ( 3 bottles per 


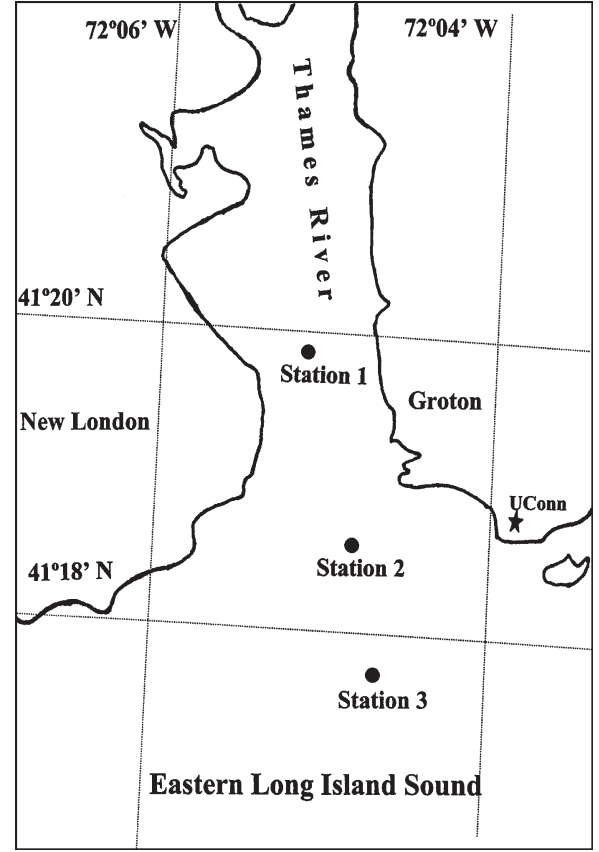

Fig. 2. Location of sampling stations in present study

station), and kept in the dark and close to in situ temperature. Upon return to the laboratory, $250 \mathrm{ml}$ from each bottle was filtered slowly through a GF/F filter paper to collect $\mathrm{DMSP}_{\mathrm{s}}$. The filtrate was collected for $\mathrm{DMSP}_{\mathrm{d}}$ and DMS analysis. Another $250 \mathrm{ml}$ from each bottle was first passed through a $10 \mathrm{~mm}$ nylon sieve, and then filtered through a GF/F filter paper to collect $\mathrm{DMSP}_{\mathrm{s}}$ of the size fraction $<10 \mathrm{~mm}$. The $\mathrm{DMSP}_{\mathrm{d}}$ and DMS samples were analyzed immediately after filtration. The DMS concentration of the filtrate was first measured with the purge-and-trap technique (Kiene \& Service 1991), then the remaining $\mathrm{DMSP}_{d}$ was converted to DMS by cold-alkaline hydrolysis (Dacey \& Blough 1987) and quantified with the purge-andtrap technique using a Shimadzu GC-FPD system. $\mathrm{DMSP}_{\mathrm{s}}$ samples were stored in serum vials at $-70^{\circ} \mathrm{C}$ until they were measured as described by Tang et al. (1999).

Chlorophyll and seston carbon. Two-liter polycarbonate bottles were filled with surface seawater (3 bottles per station) and kept in the dark and close to in situ temperature. $500 \mathrm{ml}$ from each bottle was filtered onto a GF/F filter paper and stored at $-70^{\circ} \mathrm{C}$ until the samples were ready for analysis. Chlorophyll was extracted in $90 \%$ acetone overnight and measured by the fluorescence method (Parsons et al. 1984). Seston carbon was collected by filtering $500 \mathrm{ml}$ from each bottle onto a combusted GF/F filter paper, and then measured with a Carlo-Erba CHNS analyzer.
Zooplankton abundance and DMSP $_{\mathbf{z}}$. On Day 2 of each sampling trip, zooplankton were collected from each station by towing a standard ring net $(0.5 \mathrm{~m}$ mouth diameter, $202 \mu \mathrm{m}$ mesh) in the upper $1 \mathrm{~m}$. The first tow was done with a filtering cod-end $(120 \mu \mathrm{m}$ mesh) and the cod-end content was preserved in $30 \%$ formaldehyde for abundance measurements. The towed volume was recorded with a propeller-type flow meter (General Oceanic) mounted at the mouth of the net. Three subsamples (5 to $10 \mathrm{ml}$ each) were taken from each preserved sample, identified and counted under a stereomicroscope. Species-specific abundance for each station was calculated as the total number of individuals divided by the towed volume. The second tow was done with a solid cod-end to minimize damage to the zooplankton. The cod-end content from the second tow was maintained in surface seawater on board. Upon return to the laboratory, individuals of the dominant species in the samples were immediately sorted for measuring $\mathrm{DMSP}_{\mathrm{z}}$ following the procedures described by Tang et al. (1999). $\mathrm{DMSP}_{\mathrm{z}}$ is defined here as DMSP associated with zooplankton without distinguishing between body tissues and gut content. For each station, $\mathrm{DMSP}_{\mathrm{z}}$ for each zooplankton group was calculated as species-specific $\operatorname{DMSP}_{\mathrm{z}}$ multiplied by abundance. Note that because the abundance samples and the $\mathrm{DMSP}_{\mathrm{z}}$ samples were processed separately, there were times when certain species counted for abundance were missing in the DMSP analyses. In those cases, the $\mathrm{DMSP}_{\mathrm{z}}$ was assumed to be equal to that of the same species from adjacent months, or the same months of different years.

\section{RESULTS}

\section{Temperature, salinity and seston}

The surface-water temperature decreased to a minimum of $2^{\circ} \mathrm{C}$ in January 1999 before it slowly increased to a maximum of $25^{\circ} \mathrm{C}$ in August 1999 (Fig. 3). There was a slight horizontal salinity gradient along the 3 stations, which became strong in January and June (Fig. 3). Chlorophyll was measured only between December 1998 and July 1999. Chlorophyll concentrations ranged from 0.19 to $5.64 \mathrm{\mu g} \mathrm{l}^{-1}$, and averaged $1.80 \mu \mathrm{g} \mathrm{l^{-1 }}$ (Table 1). Seston carbon concentration, which was measured between December and October, ranged from 80 to $590 \mu \mathrm{gl}^{-1}$, with an average of $300 \mu \mathrm{g} \mathrm{l}^{-1}$ (Table 1).

\section{$\operatorname{DMSP}_{\mathrm{s}} \mathbf{D M S P}_{\mathrm{d}}$ and DMS}

DMSP $_{\mathrm{s}}$ concentration was $\leq 10 \mathrm{nM}$ during most of the year, except between July and August, when it in- 

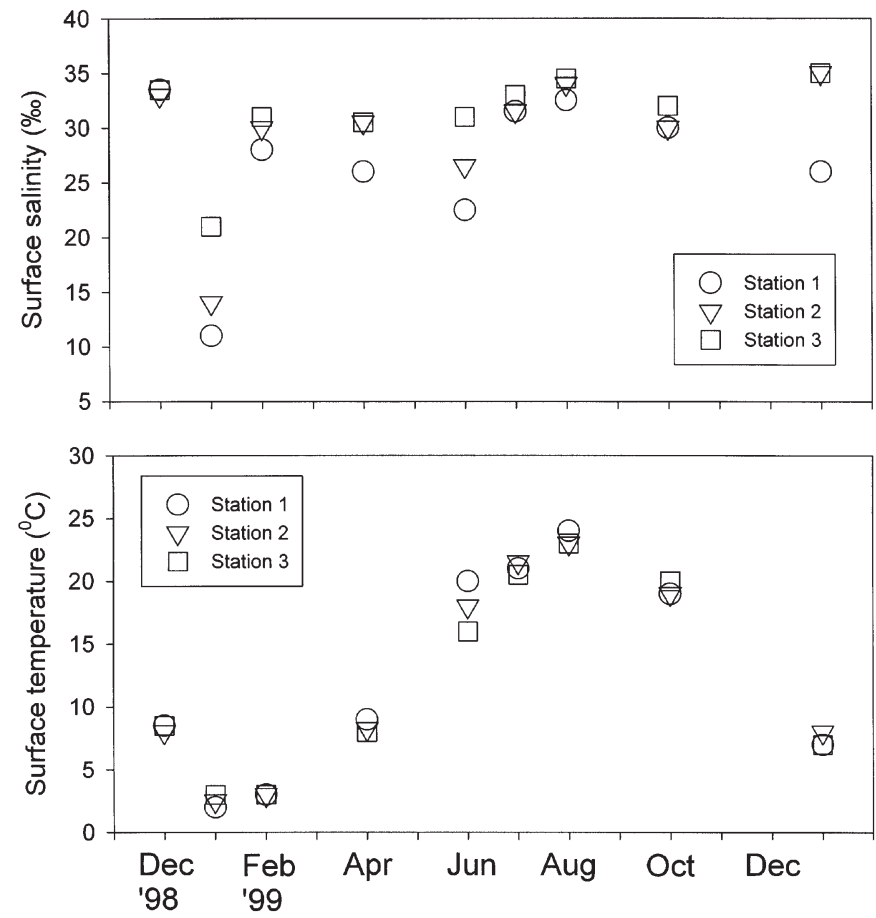

Fig. 3. Surface water salinity and temperature during the present study creased to $50 \mathrm{nM}$ (Fig. 4). The sudden increase in seston DMSP could not be attributed to changes in water temperature or salinity. Most of the time about half or more of the seston DMSP came from particles $<10 \mu \mathrm{m}$. The concentrations of $\mathrm{DMSP}_{\mathrm{d}}$ and DMS were low $(<3 \mathrm{nM})$ throughout the study. Neither $\mathrm{DMSP}_{\mathrm{d}}$ nor DMS correlated with $\mathrm{DMSP}_{\mathrm{s}}(\mathrm{p}>0.05$, Student's $t$-test), but there was a significant correlation between DMS and $\mathrm{DMSP}_{\mathrm{d}}(\mathrm{r}=0.83, \mathrm{p}<0.01$, Student's $t$-test) (Fig. 5).

\section{Zooplankton abundance and $\operatorname{DMSP}_{\mathrm{z}}$}

The zooplankton assemblages were mostly dominated by copepods. The abundances of the most common copepod species in the samples are shown in Fig. 6. Acartia spp. consisted of A. tonsa and A. hudsonica, Centropages spp. represented a mixture of C. hamatus and C. typicus. These congeneric species closely resemble each other and were not separated in the present study. The small copepods consisted of mostly small calanoid copepods such as Paracalanus spp., and cyclopoid copepods. The zooplankton abundance peaked in January and April of 1999, but remained low the rest of the year. Small copepods

Table 1. Chemical characteristics of seston between December 1998 and October 1999. Formula weight for DMSP is 135. Chl: chlorophyll

\begin{tabular}{|c|c|c|c|c|c|c|}
\hline Month & Station & $\begin{array}{c}\mathrm{Chl} \\
\left(\mu \mathrm{g} \mathrm{l}^{-1}\right)\end{array}$ & $\begin{array}{c}\mathrm{C} \\
\left(\mathrm{mg} \mathrm{l}^{-1}\right)\end{array}$ & $\begin{array}{l}\text { DMSP:chl } \\
\left(\mathrm{nmol} \mu \mathrm{g}^{-1}\right)\end{array}$ & $\begin{array}{l}\text { DMSP:C } \\
\left(\mathrm{mg} \mathrm{g}^{-1}\right)\end{array}$ & $\begin{array}{c}\mathrm{C}: \mathrm{chl}^{-1} \\
\left(\mathrm{mg} \mathrm{mg}^{-1}\right)\end{array}$ \\
\hline \multirow[t]{3}{*}{ December } & 1 & 0.28 & 0.08 & 25.6 & $1.21 \times 10^{-2}$ & 286 \\
\hline & 2 & 0.22 & 0.10 & 27.2 & $7.76 \times 10^{-3}$ & 473 \\
\hline & 3 & 0.19 & 0.11 & 42.3 & $1.01 \times 10^{-2}$ & 568 \\
\hline \multirow[t]{3}{*}{ January } & 1 & 1.00 & 0.54 & 3.5 & $8.73 \times 10^{-4}$ & 541 \\
\hline & 2 & 0.86 & 0.59 & 3.2 & $6.37 \times 10^{-4}$ & 685 \\
\hline & 3 & 0.97 & 0.47 & 3.5 & $9.78 \times 10^{-4}$ & 479 \\
\hline \multirow[t]{3}{*}{ February } & 1 & 1.77 & 0.35 & 2.5 & $1.68 \times 10^{-3}$ & 199 \\
\hline & 2 & 1.33 & 0.41 & 3.0 & $1.33 \times 10^{-3}$ & 306 \\
\hline & 3 & 1.48 & 0.28 & 2.2 & $1.58 \times 10^{-3}$ & 190 \\
\hline \multirow[t]{3}{*}{ April } & 1 & 1.77 & 0.33 & 2.4 & $1.75 \times 10^{-3}$ & 184 \\
\hline & 2 & 1.80 & 0.17 & 2.3 & $3.27 \times 10^{-3}$ & 96 \\
\hline & 3 & 0.94 & 0.18 & 3.9 & $2.82 \times 10^{-3}$ & 187 \\
\hline \multirow[t]{3}{*}{ June } & 1 & 2.85 & 0.51 & 0.4 & $3.22 \times 10^{-4}$ & 180 \\
\hline & 2 & 2.22 & 0.35 & 1.2 & $1.01 \times 10^{-3}$ & 157 \\
\hline & 3 & 1.71 & 0.31 & 2.8 & $2.10 \times 10^{-3}$ & 179 \\
\hline \multirow[t]{3}{*}{ July } & 1 & 5.64 & 0.36 & 7.7 & $1.64 \times 10^{-2}$ & 63 \\
\hline & 2 & 4.62 & 0.29 & 11.2 & $2.47 \times 10^{-2}$ & 62 \\
\hline & 3 & 2.74 & 0.24 & 16.3 & $2.56 \times 10^{-2}$ & 86 \\
\hline \multirow[t]{3}{*}{ August } & 1 & & 0.19 & & $2.88 \times 10^{-2}$ & \\
\hline & 2 & & 0.26 & & $1.11 \times 10^{-2}$ & \\
\hline & 3 & & 0.23 & & $5.50 \times 10^{-3}$ & \\
\hline \multirow[t]{3}{*}{ October } & 1 & & 0.32 & & $4.05 \times 10^{-3}$ & \\
\hline & 2 & & 0.32 & & $3.32 \times 10^{-3}$ & \\
\hline & 3 & & 0.32 & & $2.86 \times 10^{-3}$ & \\
\hline Average (SD) & & $1.79(1.45)$ & $0.30(0.13)$ & $8.9(11.6)$ & $7.11 \times 10^{-3}\left(8.56 \times 10^{-3}\right)$ & $273(192)$ \\
\hline
\end{tabular}




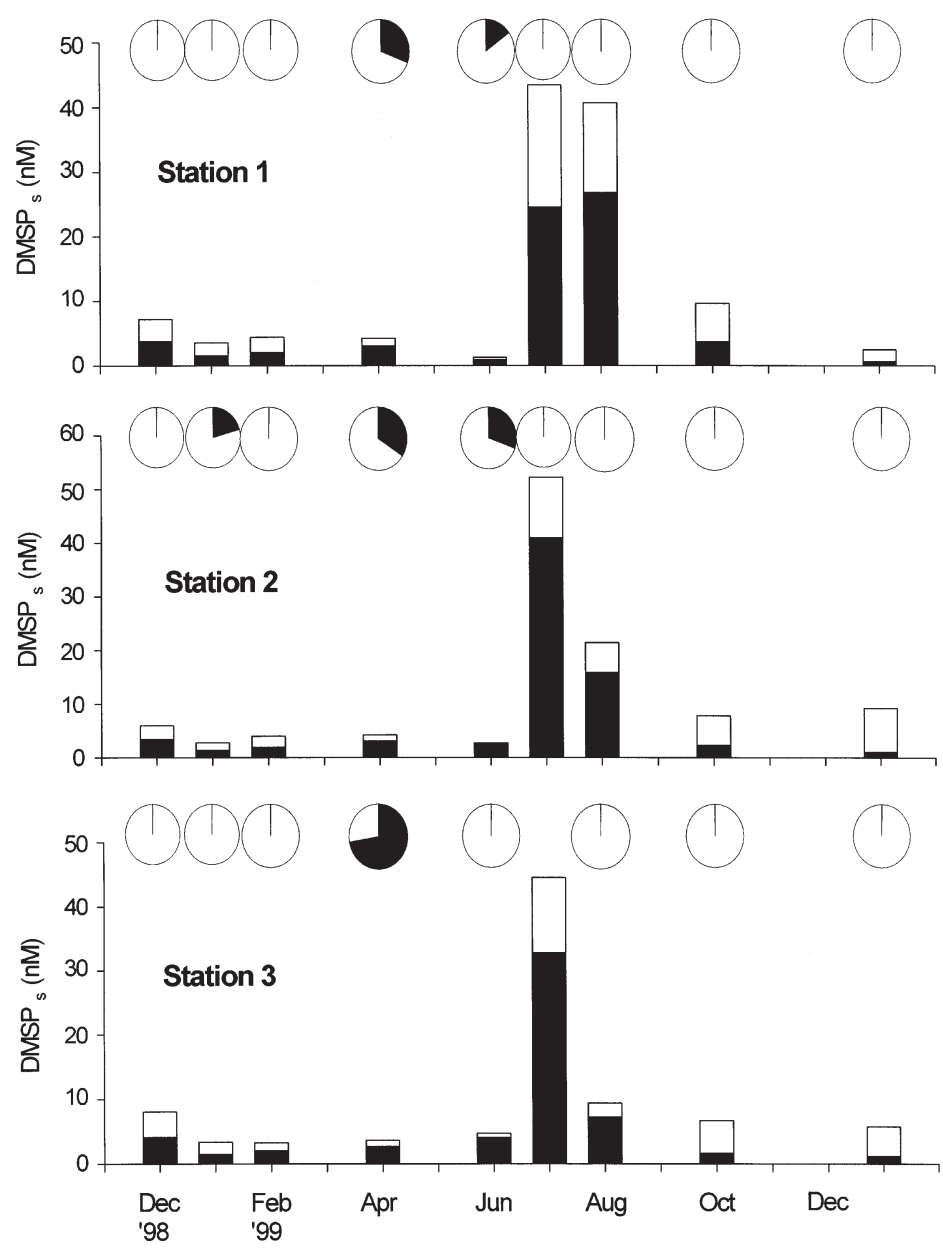

Fig. 4. Bar charts show concentrations of seston DMSP $\left(\mathrm{DMSP}_{\mathrm{s}}\right.$ ). Filled bars: particles $<10 \mu \mathrm{m}$ (unfilled bars: particles $>10 \mu \mathrm{m}$ ). Pie charts show percentage (filled portions) of total particulate DMSP associated with zooplankton $\left(\mathrm{DMSP}_{\mathrm{z}}\right)$. $\mathrm{DMSP}_{\mathrm{z}}$ is calculated for each station as species-specific DMSP content multiplied by abundance. See 'Materials and methods' for explanation

dominated the assemblages most of the year, except in April when Temora longicornis was the most abundant species. On several occasions other types of zooplankton were found in substantial abundance, such as marine cladocerans (Podon sp. and Evadne sp.) and planktonic larvae (Table 2).

All zooplankton samples contained DMSP, and species-specific $\mathrm{DMSP}_{\mathrm{z}}$ varied by 3 orders of magnitude (Table 2). The large copepods Centropages spp. and Temora longicornis contained more DMSP (average 0.3 and $2.8 \mathrm{nmol} \mathrm{ind.}^{-1}$ ) than the smaller Acartia spp. and small copepods (average 18 and $41 \mathrm{pmol}^{\text {ind }} \mathrm{-}^{-1}$ ). Cladocerans and bivalve larvae contained the smallest amount of DMSP (1 to 2 pmol ind. ${ }^{-1}$ ). DMSP contents of $T$. longicornis were measured directly with no estimation required (see 'Materials and methods'). The high
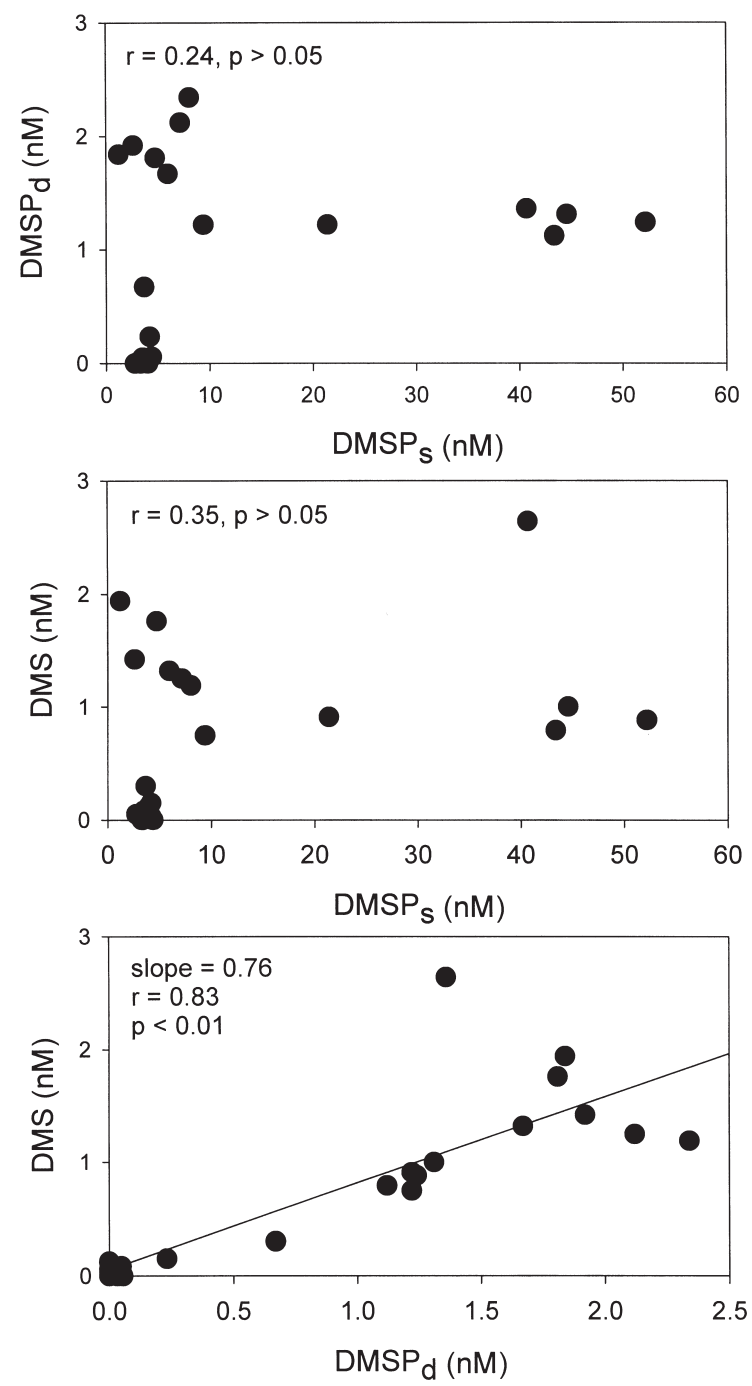

Fig. 5. Relationship between dissolved DMSP $\left(\mathrm{DMSP}_{\mathrm{d}}\right)$, DMS and seston DMSP $\left(\mathrm{DMSP}_{\mathrm{s}}\right)$. Correlation coefficients (r) and significance level (p) are also presented

DMSP contents of Centropages spp. and T. longicornis were observed when DMSP $_{\mathrm{s}}$ was relatively low, while the DMSP content of Acartia spp. remained low even at higher $\mathrm{DMSP}_{\mathrm{s}}$ (Fig. 7). These observations indicate that the difference in body DMSP contents reflects a true species-specific variation instead of external DMSP $_{\mathrm{s}}$ supply (cf. Tang et al. 1999, Tang 2000).

For each station, total $\mathrm{DMSP}_{\mathrm{z}}$ was computed as the summation of species-specific $\mathrm{DMSP}_{\mathrm{z}}$ multiplied by the species abundance. Total particulate DMSP $\left(\mathrm{DMSP}_{\mathrm{p}}\right)$ was calculated as $\mathrm{DMSP}_{\mathrm{s}}+\mathrm{DMSP}_{\mathrm{z}}$ and the contribution of zooplankton to the total particulate DMSP was calculated as:

$$
\% \mathrm{DMSP}_{\mathrm{p}}=\frac{\mathrm{DMSP}_{\mathrm{z}}}{\mathrm{DMSP}_{\mathrm{s}}+\mathrm{DMSP}_{\mathrm{z}}} \times 100 \%
$$




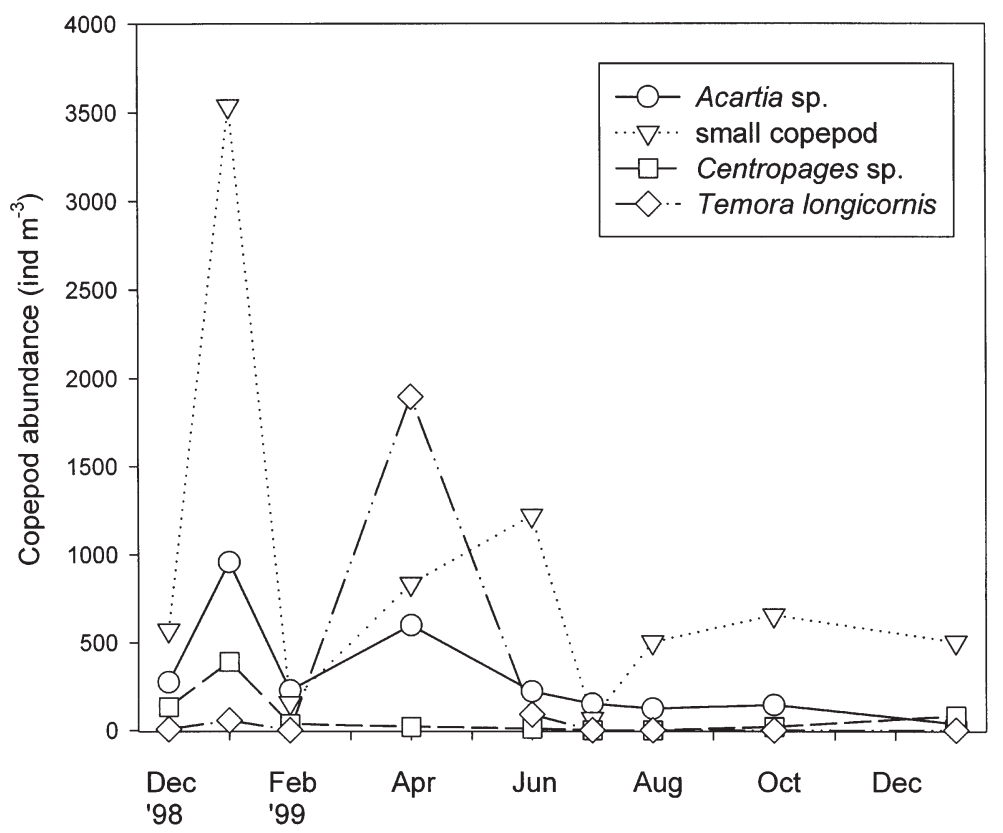

Fig. 6. Average copepod abundances (ind. $\mathrm{m}^{-3}$ ) in present study

\section{DISCUSSION}

\section{$\mathrm{DMSP}_{\mathrm{s}}, \mathrm{DMSP}_{\mathrm{d}}$ and DMS}

The range of $\mathrm{DMSP}_{\mathrm{s}}$ observed in the present study was comparable to that in 4 other estuaries (Iverson et al. 1989), but considerably less than in some other coastal waters (Kiene \& Service 1991, Kiene \& Gerard 1995, Kiene 1996a). We observed a stronger correlation between $\mathrm{DMSP}_{\mathrm{d}}$ and DMS in the present study than that derived by Kettle et al. (1999) from a global database. This stronger correlation indicates that the accumulation of dissolved DMSP and DMS were tightly coupled. If one assumes a steady-state condition, the DMSP $_{\mathrm{d}}$-to-DMS conversion efficiency can be estimated from the slope of linear regression, which is $76 \%$ in the present case (Fig. 5). This high efficiency is consistent with the view that dissolved DMSP is efficiently consumed by bacteria in coastal waters (Kiene \& Service 1991, Kiene \& Gerard 1995), yet higher than the conversion efficiencies measured in some studies (Kiene 1996b, van Duyl et al. 1998, Simó \& Pedrós-Alió 1999). In contrast, $\mathrm{DMSP}_{\mathrm{d}}$ and DMS did not correlate with $\mathrm{DMSP}_{\mathrm{s}}$ (Fig. 5), implying that the accumulation of seston DMSP and dissolved DMSP were uncoupled. As shown in Fig. 1, the flux between phytoplankton DMSP and dissolved DMSP can be disrupted by the presence of microzooplankton and zooplankton. For example, microzooplankton grazing may lead to DMSP destruction (Wolfe et al. 1994), while zooplankton grazing may reduce dissolved DMSP formation (by the zooplankters retaining DMSP in their bodies) (Tang et al. 1999), or

Table 2. Average DMSP content of zooplankton in present study. For non-copepods, months of appearance and mean abundance are also indicated (see Fig. 6 for monthly abundance of copepods). n: number of measurements. Each measurement used 1 to 50 individuals

\begin{tabular}{|c|c|c|c|c|c|}
\hline \multirow[t]{2}{*}{ Zooplankters } & \multicolumn{3}{|c|}{ DMSP (mol ind..$^{-1}$ ) } & \multirow[t]{2}{*}{ Month } & \multirow[t]{2}{*}{ Ind. $\mathrm{m}^{-3}$} \\
\hline & Mean & SD & $\mathrm{n}$ & & \\
\hline \multicolumn{6}{|l|}{ Copepods } \\
\hline Acartia spp. & $1.76 \times 10^{-11}$ & $1.39 \times 10^{-11}$ & 80 & & \\
\hline Small copepods & $4.12 \times 10^{-11}$ & $5.59 \times 10^{-11}$ & 22 & & \\
\hline Centropages spp. & $3.25 \times 10^{-10}$ & $2.53 \times 10^{-10}$ & 39 & & \\
\hline Temora longicornis & $2.81 \times 10^{-9}$ & $1.11 \times 10^{-9}$ & 39 & & \\
\hline \multicolumn{6}{|l|}{ Non-copepods } \\
\hline Snail larvae & $1.18 \times 10^{-10}$ & $3.29 \times 10^{-11}$ & 5 & Jun & 87 \\
\hline Barnacle larvae & $3.35 \times 10^{-12}$ & $3.09 \times 10^{-12}$ & 3 & Jun & 53 \\
\hline Marine cladocerans & $9.63 \times 10^{-13}$ & $8.51 \times 10^{-13}$ & 3 & Jun & 843 \\
\hline Unknown eggs & $1.18 \times 10^{-11}$ & $1.05 \times 10^{-11}$ & 6 & Jun & 107 \\
\hline Decapod larvae & $2.31 \times 10^{-10}$ & $1.82 \times 10^{-10}$ & 12 & Apr, Jul, Aug, Oct & 187 \\
\hline Bivalve larvae & $1.69 \times 10^{-12}$ & $3.34 \times 10^{-13}$ & 7 & Dec, Jan & 2105 \\
\hline
\end{tabular}


promote its formation through osmoregulation (Tang et al. 2000) and dissolution of fecal material (Tang 2000b).

\section{DMSP in zooplankton}

A conventional wisdom is that the main pool of marine DMSP is phytoplankton; as a result, most published studies on DMSP distribution have focused only on seston. In the present study, we have shown that copepods contain DMSP, and the species-specific $\mathrm{DMSP}_{\mathrm{z}}$ contents are comparable to previous measurements (Tang et al. 1999). In addition, several other types of zooplankters also contain DMSP. The question arises: are zooplankton an important fraction of the total DMSP in the water column? As shown in Fig. 4, most of the time zooplankton were a negligible part of the DMSP budget. However, on several occasions when Temora longicornis appeared in high abundance, zooplankton represented a significant portion of the DMSP budget. A similar spring-time increase in the abundance of $T$. longicornis has been reported for other parts of Long Island Sound. For example, in central Long Island Sound, the abundance of female T. longiCornis increases up to 5500 ind. $\mathrm{m}^{-3}$ in the spring (Dam \& Peterson 1993), which is more than twice the maximum abundance observed in the present study. When all stages (N1 to adult) are considered, the population of T. longicornis could reach densities of up to $5 \times 10^{4} \mathrm{~m}^{-3}$ (Peterson 1985). Since traditional water-sampling methods are not appropriate for collecting actively swimming zooplankters, $\mathrm{DMSP}_{\mathrm{z}}$ can be regarded as an often underestimated pool of particulate DMSP. This was clearly the case in April (Stn 3), when $\mathrm{DMSP}_{\mathrm{z}}$ exceeded $\mathrm{DMSP}_{\mathrm{s}}$. It is not known why T. longicornis con-

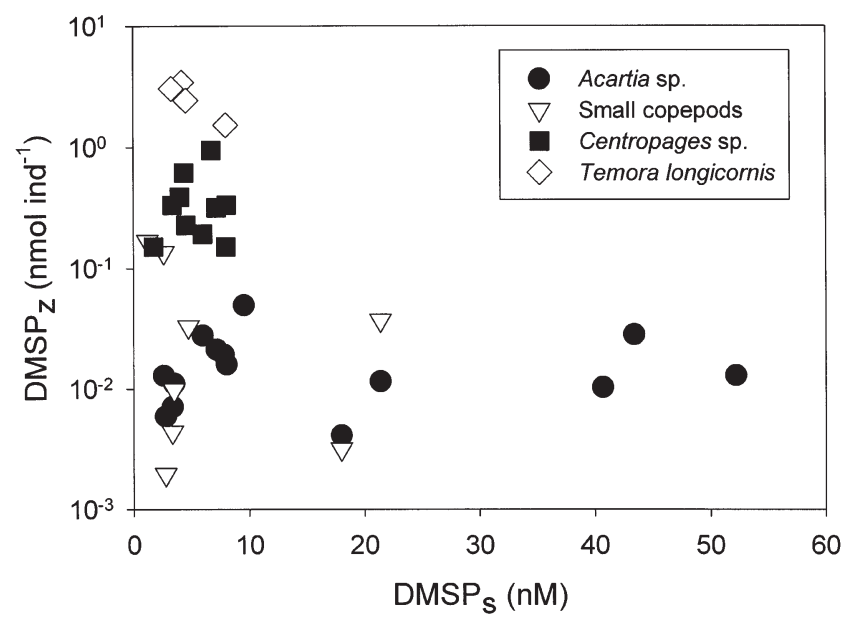

Fig. 7. Relationship between DMSP content of copepods $\left(\mathrm{DMSP}_{\mathrm{z}}\right)$ and seston DMSP $\left(\mathrm{DMSP}_{\mathrm{s}}\right)$. Notice that $y$-axis is on log scale tains more DMSP than other zooplankton species. Large inter-specific variation in cellular DMSP content has also been observed in phytoplankton under identical culturing conditions (Keller \& Korjeff-Bellows 1996), but the reason for this variation is not well understood. The relatively large amount of DMSP in T. longicornis is not due to a higher osmoregulatory demand, since laboratory experiments have shown that the amount of DMSP does not affect the survival of the copepods under fluctuating salinties (Tang et al. 1999). DMSP also appears to be a minor osmolyte pool relative to free amino acids in other copepod species. For example, Tang et al. (1999) estimated that body DMSP concentration was 2 to 3 orders of magnitude lower than free amino acid concentration in the copepod Acartia tonsa.

\section{DMSP turnover in copepods}

In central Long Island Sound, Temora longicornis may satisfy carbon demand by grazing at a rate of 3 ng chlorophyll ind. ${ }^{-1} \mathrm{~h}^{-1}$ (Dam \& Peterson 1991, 1993, Peterson \& Dam 1996). In our study, the ambient chlorophyll concentration was $1.5 \mathrm{mg} \mathrm{l}^{-1}$ in April, when T. longicornis appeared in high abundance. At this chlorophyll concentration, the required clearance rate would be $2 \mathrm{ml}$ ind. ${ }^{-1} \mathrm{~h}^{-1}$, which is comparable to normal clearance rates for this species (Dam 1986). Thus, T. longicornis could rely solely on phytoplankton for food. At this clearance rate, $T$. longicornis would ingest 8 pmol DMSP $_{\mathrm{s}}$ ind. ${ }^{-1} \mathrm{~h}^{-1}$. The turnover time for DMSP in $T$. longicornis can be estimated as the average $\mathrm{DMSP}_{\mathrm{z}}$ for $T$. longicornis (2.81 nmol ind $\mathrm{.}^{-1}$ ) divided by $\mathrm{DMSP}_{\mathrm{s}}$ ingestion rate; this yields a turnover time of $15 \mathrm{~d}$, which is comparable to previous laboratory estimates (Tang et al. 1999).

Assuming a cylindrical shape, we estimated the biovolume of the copepods based on their typical linear dimensions, and then calculated their body DMSP concentrations. In most cases, the body DMSP concentrations of the copepods were orders of magnitude higher than that of ambient $\mathrm{DMSP}_{\mathrm{s}}$ and $\mathrm{DMSP}_{\mathrm{d}}$ (Table 3). Therefore, while $\mathrm{DMSP}_{\mathrm{s}}$ and $\mathrm{DMSP}_{\mathrm{d}}$ are diffusely distributed in the ocean, copepod bodies represent highly concentrated pockets of DMSP in the water column. Bacterial degradation of DMSP is a major biogeochemical pathway in DMSP dynamics (Kiene \& Service 1991, Kiene 1992, Visscher \& Taylor 1994), and copepod bodies and their fecal material are often colonized by bacteria (Delille \& Razouls 1994, Hansen \& Bech 1996). Thus, the locally elevated DMSP concentrations associated with copepod bodies (this study) and fecal material (Tang 2000b) may represent 'hot spots' for microbial DMSP-turnover in the water column. This hypothesis will be examined further in another study. 
Table 3. Estimated DMSP concentrations in copepod bodies. L: typical body length; W: typical body width; V: estimated body volume assuming cylindrical shape. Range of seston and dissolved DMSP concentrations (nM) are given for comparison

\begin{tabular}{|lccccc|}
\hline & $\begin{array}{c}\mathrm{L} \\
(\mathrm{mm})\end{array}$ & $\begin{array}{c}\mathrm{W} \\
(\mathrm{mm})\end{array}$ & $\begin{array}{c}\mathrm{V} \\
(\mathrm{l})\end{array}$ & $\begin{array}{c}\text { Body content } \\
\left(\text { mol DMSP ind }^{-1}\right)\end{array}$ & $\begin{array}{c}\text { Concentration } \\
(\mathrm{nM} \text { DMSP) }\end{array}$ \\
\hline Acartia spp. & 0.5 & 0.25 & $2.5 \times 10^{-8}$ & $1.77 \times 10^{-11}$ & $7.2 \times 10^{5}$ \\
Small copepods & 0.2 & 0.1 & $1.6 \times 10^{-9}$ & $3.68 \times 10^{-11}$ & $2.3 \times 10^{7}$ \\
Centropages spp. & 2 & 0.5 & $3.9 \times 10^{-5}$ & $4.49 \times 10^{-10}$ & $1.2 \times 10^{4}$ \\
Temora longicornis & 1.5 & 0.5 & $2.9 \times 10^{-5}$ & $2.81 \times 10^{-9}$ & $9.7 \times 10^{4}$ \\
Seston DMSP & & & & & $1.22-52.2$ \\
Dissolved DMSP & & & & $0-2.34$ \\
\hline
\end{tabular}

\section{Role of non-phytoplankton particles}

In the present study, as in most DMSP field studies, the actual composition of the seston was not determined. However, knowing the composition of the seston material is important to understanding how the food web structure may affect DMSP dynamics (Fig. 1). Since the C:chlorophyll ratios (Table 1) were about 5 times higher than the typical values for phytoplankton (Omori \& Ikeda 1992), and DMSP $_{\mathrm{s}}$ :chlorophyll ratios (Table 1) were comparable to that of phytoplankton cultures (Keller \& Korjeff-Bellows 1996), we suggest that most $\mathrm{DMSP}_{\mathrm{s}}$ was derived from phytoplankton, and that microzooplankton and detritus contained negligible DMSP. In the literature, $\mathrm{DMSP}_{\mathrm{s}}$ :chlorophyll ratios can vary widely. For example, Townsend \& Keller (1996) reported average $\mathrm{DMSP}_{\mathrm{s}}$ :chlorophyll ratios of 3 to $16 \mathrm{nmol} \mathrm{gg}^{-1}$ in the Gulf of Maine, similar to the ratios for phytoplankton. In the NE Atlantic (Belviso et al. 1993, Malin et al. 1993) and St. Lawrence estuary

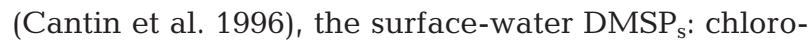
phyll ratios are on the order of $100 \mathrm{nmol} \mathrm{ug}^{-1}$, which is much higher than for most phytoplankton. In 4 estuary-shelf systems on the east coast of the USA, Iverson et al. (1989) observed $\mathrm{DMSP}_{\mathrm{s}}$ :chlorophyll ratios of

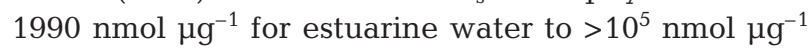
for oceanic water, which is $\geq 3$ orders of magnitude higher than any known DMSP:chlorophyll ratio for phytoplankton cultures (Keller \& Korjeff-Bellows 1996, Wolfe \& Steinke 1996). The high $\mathrm{DMSP}_{\mathrm{s}}$ :chlorophyll ratios reported in these studies could be explained by low chlorophyll content or elevated DMSP content of the phytoplankton. However, these 2 explanations are unlikely under the suboptimal light (Falkowski 1980), nutrient-rich (Keller \& Korjeff-Bellows 1996) conditions of coastal waters. A plausible explanation for the high $\mathrm{DMSP}_{\mathrm{s}}$ :chlorophyll ratios is that a significant portion of the seston DMSP was derived from particles that contain no chlorophyll, i.e. non-phytoplankton particles, such as microzooplankton and detritus. Based on analyses of nonphotosynthetic pigments, Belviso et al. (1993) also suggested that a substantial portion of particulate DMSP in the NE Atlantic could be derived from microzooplankton and detritus.

\section{Pelagic food web and DMSP dynamics}

The presence of DMSP in non-phytoplankton components in the pelagic food web begs for a revision of our understanding of DMSP dynamics in the oceans. Most models of DMSP dynamics rely heavily on what is known about the physiology and ecology of phytoplankton. However, our study has shown that, at times, a substantial portion of particulate DMSP is derived from zooplankton; therefore, phytoplankton-based processes are not entirely sufficient for understanding the dynamics of DMSP in the water column. Although recent conceptual DMSP models include zooplankton, their role in the models is largely limited to grazing or sloppy feeding (e.g. Kiene \& Bates 1990, Gabric et al. 1993, van den Berg et al. 1996). Not only is the concept of zooplankton sloppy feeding misused in the literature (discussed by Tang et al. 2000), but also the presence of DMSP in zooplankton biomass (Tang et al. 1999, Tang 2000a, this study), fecal material (Kwint et al. 1996, Tang 2000b), and the biochemical fate of DMSP in these 2 pools (Tang 2000a,b, Tang et al. 2000) have often been ignored.

DMSP has long been recognized as an important compound in the sulfur cycle and global climate regulation, yet researchers should extend their efforts beyond phytoplankton and bacteria, and begin to explore DMSP dynamics in terms of complex ecological interactions among different components in the water column (Fig. 1). Based on the present study, several suggestions for future studies can be made: (1) The present study covered only a few types of zooplankton. Given the large inter-specific variations in their body DMSP content, it is premature to generalize the global importance of zooplankton as a standing stock of DMSP in the ocean. Therefore, there is a need to establish a database of DMSP content of different zooplankton species from different oceanic regimes. 
(2) The impacts of zooplankton on DMSP dynamics can be categorized as 'repackaging' or 'storing-repackaging'. The first category includes Acartia spp., Centropages spp., small copepods, marine cladocerans and planktonic larvae. These groups of zooplankters contain very little DMSP in their bodies and, therefore they affect DMSP dynamics mostly through grazing and repackaging DMSP into fecal material (Daly \& DiTullio 1996, Kwint et al. 1996, Tang 2000a,b) or dissolved DMSP (Dacey \& Wakeham 1986). The second, a less common category, is represented by the copepod Temora longicornis, which has a considerable amount of DMSP in its body. As a result, in addition to grazing and repackaging, the biochemical fate of DMSP in its body also needs to be considered (e.g. Tang et al. 1999, 2000). By assigning zooplankters into the 2 categories, researchers can better model the seasonal dynamics of DMSP and the corresponding role of zooplankton. (3) Seasonal increases in zooplankton population often lag behind phytoplankton blooms. Zooplankters may remove DMSP from the surface water by repackaging phytoplankton DMSP into sinking fecal pellets, and lengthen the residence time of DMSP in the upper water column by storing ingested DMSP in their biomass, resulting in an uncoupling between phytoplankton DMSP production and DMS formation (Fig. 8). Therefore, the population dynamics of planktonic grazers needs to be considered when deciding an appropriate observation period for the study of phytoplankton bloom dynamics and DMS production. (4) Since each of the seston components (phytoplankton, microzooplankton, and detritus) interacts with zooplankton differently, the resultant DMSP fluxes will also be different. Thus, to better understand the dynamics of DMSP within the pelagic food web, differentiation of seston components will be a difficult, yet necessary task in future DMSP studies.

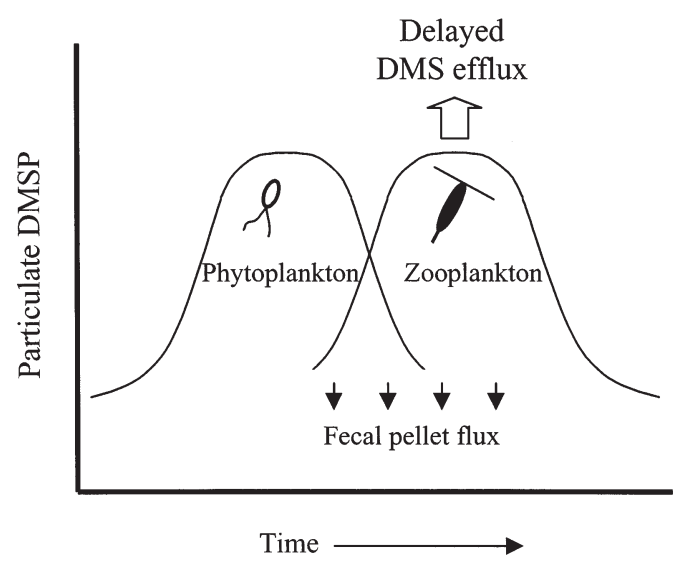

Fig. 8. Conceptual diagram of phyto- and zooplankton population dynamics and effects on DMS production
Acknowledgements. This study is supported by NSF OCE9521907 (CAREER) and a small GIA from the University of Connecticut (UCONN) awarded to H.G.D., NSF OCE-9714900 awarded to P.T.V., and Sigma Xi GIAR awarded to K.W.T. We thank L. Burch for assistance with field work. The Marine Science and Technology Center (MSTC) of UCONN provided research vessels. This is contribution no. 310 of the MSTC, UCONN.

\section{LITERATURE CITED}

Andreae MO (1990) Ocean-atmospheric interactions in the global biogeochemical sulfur cycle. Mar Chem 30:1-29

Andreae MO, Raemdonck H (1983) Dimethyl sulfide in the surface ocean and the marine atmosphere: a global view. Science 221:744-747

Bates TS, and 7 co-authors (1994) The cycling of sulfur in surface seawater of the northeast Pacific. J Geophys Res 99: 7835-7843

Belviso S, Buat-Ménard P, Putaud JP, Nguyen BC, Claustre H, Neveux J (1993) Size distribution of dimethylsulfoniopropionate (DMSP) in areas of the tropical northeastern Atlantic Ocean and the Mediterranean Sea. Mar Chem 44:55-71

Bratbak G, Levasseur M, Michaud S, Cantin G, Fernandez E, Heimdal BR, Heldal M (1995) Viral activity in relation to Emiliania huxleyi blooms: a mechanism of DMSP release? Mar Ecol Prog Ser 128:133-142

Brimblecombe P, Shooter D (1986) Photo-oxidation of DMS in aqueous solution. Mar Chem 19:343-353

Cantin G, Levasseur M, Gosselin M, Michaud S (1996) Role of zooplankton in the mesoscale distribution of surface dimethylsulfide concentrations in the Gulf of St. Lawrence, Canada. Mar Ecol Prog Ser 141:103-117

Charlson RJ, Lovelock JE, Andreae MO, Warren SG (1987) Oceanic phytoplankton, atmospheric sulphur, cloud albedo and climate. Nature 326:655-661

Dacey JWH, Blough NV (1987) Hydroxide decomposition of dimethylsulfoniopropionate to form dimethylsulfide. Geophys Res Lett 14:1246-1249

Dacey JWH, Wakeham SG (1986) Oceanic dimethylsulfide: production during zooplankton grazing on phytoplankton. Science 233:1314-1316

Dacey JWH, Howse FA, Michaels AF, Wakeham SG (1998) Temporal variability of dimethylsulfide and dimethylsulfoniopropionate in the Sargasso Sea. Deep-Sea Res 45: 2085-2104

Daly KL, DiTullio GR (1996) Particulate dimethylsulfoniopropionate removal and dimethyl sulfide production by zooplankton in the Southern Ocean. In: Kiene RP, Visscher PT, Keller MD, Kirst GO (eds) Biological and environmental chemistry of DMSP and related sulfonium compounds. Plenum Press, New York, p 223-238

Dam HG (1986) Short-term feeding of Temora longicornis Müller in the laboratory and the field. J Exp Mar Biol Ecol 99:149-161

Dam HG, Peterson WT (1991) In situ feeding behavior of the copepod Temora longicornis: effects of seasonal changes in chlorophyll size fractions and female size. Mar Ecol Prog Ser 71:113-123

Dam HG, Peterson WT (1993) Seasonal contrasts in the diel vertical distribution, feeding behavior, and grazing impact of the copepod Temora longicornis in Long Island Sound. J Mar Res 51:561-594

Delille D, Razouls S (1994) Community structures of heterotrophic bacteria of copepod fecal pellets. J Plankton Res 16:603-615 
Falkowski PG (1980) Light-shade adaptation in marine phytoplankton. In: Falkowski PG (ed) Primary productivities in the sea. Plenum Press, New York, p 99-119

Gabric A, Murray N, Stone L, Kohl M (1993) Modelling the production of dimethylsulfide during a phytoplankton bloom. J Geophys Res 98:22805-22816

Hansen B, Bech G (1996) Bacteria associated with a marine planktonic copepod in culture. I. Bacterial genera in seawater, body surface, intestines and fecal pellets and succession during fecal pellet degradation. J Plankton Res 18: 257-273

Iverson RL, Nearhoof FL, Andrease MO (1989) Production of dimethylsulfonium propionate and dimethylsulfide by phytoplankton in estuarine and coastal waters. Limnol Oceanogr 34:53-67

Karsten U, Kück K, Vogt C, Kirst GO (1996) Dimethylsulfoniopropionate production in phototrophic organisms and its physiological function as a cryoprotectant. In: Kiene RP, Visscher PT, Keller MD, Kirst GO (eds) Biological and environmental chemistry of DMSP and related sulfonium compounds. Plenum Press, New York, p 143-153

Keller MD, Korjeff-Bellows W (1996) Physiological aspects of the production of dimethyl sulfoniopropionate (DMSP) by marine phytoplankton. In: Kiene RP, Visscher PT, Keller MD, Kirst GO (eds) Biological and environmental chemistry of DMSP and related sulfonium compounds. Plenum Press, New York, p 131-142

Kettle AJ, and 31 co-authors (1999) A global database of sea surface dimethylsulfide (DMS) measurements and a procedure to predict sea surface DMS as a function of latitude, longitude and month. Global Biogeochem Cycles 13: 399-444

Kiene RP (1992) Dynamics of dimethyl sulfide and dimethylsulfoniopropionate in oceanic water samples. Mar Chem 37:29-52

Kiene RP (1996a) Turnover of dissolved DMSP in estuarine and shelf waters of the northern Gulf of Mexico. In: Kiene RP, Visscher PT, Keller MD, Kirst GO (eds) Biological and environmental chemistry of DMSP and related sulfonium compounds. Plenum Press, New York, p 337-349

Kiene RP (1996b) Production of methanethiol from dimethylsulfoniopropionate in marine surface waters. Mar Chem 54:69-83

Kiene RP, Bates TS (1990) Biological removal of dimethyl sulphide from sea water. Nature 345:702-705

Kiene RP, Gerard G (1995) Evaluation of glycine betaine as an inhibitor of dissolved dimethyl sulfoniopropionate degradation in coastal waters. Mar Ecol Prog Ser 128:121-131

Kiene RP, Service SK (1991) Decomposition of dissolved DMSP and DMS in estuarine waters: dependence on temperature and substrate concentration. Mar Ecol Prog Ser 76:1-11

Kiene RP, Hoffmann Williams LP, Walker JE (1998) Seawater microorganisms have a high affinity glycine betaine uptake system which also recognizes dimethylsulfoniopropionate. Aquat Microb Ecol 15:39-51

Kirst GO (1996) Osmotic adjustment in phytoplankton and macroalgae. In: Kiene RP, Visscher PT, Keller MD, Kirst GO (eds) Biological and environmental chemistry of DMSP and related sulfonium compounds. Plenum Press, New York, p 121-129

Kwint RLJ, Irigoien X, Kramer KJM (1996) Copepods and DMSP. In: Kiene RP, Visscher PT, Keller MD, Kirst GO (eds) Biological and environmental chemistry of DMSP and related sulfonium compounds. Plenum Press, New York, p 239-252

Laroche D, and 7 co-authors (1999) DMSP synthesis and exu- dation in phytoplankton: a modeling approach. Mar Ecol Prog Ser 180: 37-49

Ledyard KM, Dacey JWH (1994) Dimethylsulfide production from dimethylsulfoniopropionate by a marine bacterium. Mar Ecol Prog Ser 110:95-103

Levasseur M, and 9 co-authors (1996) Production of DMSP and DMS during a mesocosm study of an Emiliania huxleyi bloom: influence of bacteria and Calanus finmarchicus grazing. Mar Biol 126:609-618

Lovelock JE, Maggs RJ, Rasmussen RA (1972) Atmospheric dimethyl sulphide and the natural sulphur cycle. Nature 237:452-453

Malin G, Turner S, Liss P, Holligan P, Harbour D (1993) Dimethylsulphide and dimethyl sulphoniopropionate in the Northeast Atlantic during the summer coccolithophore bloom. Deep-Sea Res 40:1487-1508

Nguyen BC, Gaudry A, Bonsang B, Lambert G (1978) Reevaluation of the role of dimethyl sulfide in the sulphur budget. Nature 275:637-639

Nguyen BC, Bonsang B, Gaudry A (1983) The role of the ocean in the global atmospheric sulfur cycle. J Geophys Res 88:10903-10914

Omori M, Ikeda T (1992) Methods in marine zooplankton ecology, 2nd edn. Krieger Press, Malabar, FL

Parsons TR, Maita Y, Lalli CM (1984) A manual of chemical and biological methods for seawater analysis. Pergamon Press, New York

Peterson WT (1985) Abundance, age structure and in situ egg production rates of the copepod Temora longicornis in Long Island Sound, New York. Bull Mar Sci 37:726-738

Peterson WT, Dam HG (1996) Pigment ingestion and egg production rates of the calanoid copepod Temora longicornis: implications for gut pigment loss and omnivorous feeding. J Plankton Res 18:855-861

Simó R, Pedrós-Alió C (1999) Short-term variability in the open ocean cycle of dimethylsulfide. Global Biogeochem Cycles 13:1173-1181

Stefels J, van Boekel WHM (1993) Production of DMS from dissolved DMSP in axenic cultures of the marine phytoplankton species Phaeocystis sp. Mar Ecol Prog Ser 97: $11-18$

Tang KW (2000a) Dynamics of dimethylsulfoniopropionate (DMSP) in a migratory grazer: a laboratory simulation study. J Exp Mar Biol Ecol 243:283-293

Tang KW (2000b) Role of the estuarine copepod Acartia tonsa in DMSP dynamics. Abstract, ASLO Aquatic Sciences Meeting, Copenhagen

Tang KW, Dam HG, Visscher PT, Fenn TD (1999) Dimethylsulfoniopropionate (DMSP) in marine copepods and its relation with diets and salinity. Mar Ecol Prog Ser 179: 71-793

Tang KW, Fenn TD, Visscher PT, Dam HG (2000) Regulation of body dimethyl sulfoniopropionate (DMSP) content by the copepod Temora longicornis: a test of four mechanisms. Mar Biol 136:749-757

Townsend DW, Keller MD (1996) Dimethylsulfide (DMS) and dimethylsulfoniopropionate (DMSP) in relation to phytoplankton in the Gulf of Maine. Mar Ecol Prog Ser 137: 229-241

Turner SM, Malin G, Liss PS, Harbour DS, Holligan PM (1988) The seasonal variation of dimethyl sulfide and dimethylsulfoniopropionate concentrations in nearshore waters. Limnol Oceanogr 33:364-375

van den Berg AJ, Turner SM, van Duyl FC, Ruardij P (1996) Model structure and analysis of dimethylsulphide (DMS) production in the southern North Sea, considering phytoplankton dimethylsulphoniopropionate-(DMSP) lyase and 
eutrophication effects. Mar Ecol Prog Ser 145:233-244

van Duyl FC, Gieskes WWC, Kop AJ, Lewis WE (1998) Biological control of short-term variation in the concentration of DMSP and DMS during a Phaeocystis spring bloom. J Sea Res 40:221-231

Visscher PT, Taylor BF (1993) A new mechanism for the aerobic catabolism of dimethyl sulfide. Appl Environ Microbiol 59:3784-3789

Visscher PT, Taylor BF (1994) Demethylation of dimethylsulfoniopropionate to 3-mercaptopropionate by an aerobic marine bacterium. Appl Environ Microbiol 60:4617-4619

Visscher PT, Diaz MR, Taylor BF (1992) Enumeration of bac-

Editorial responsibility: Otto Kinne (Editor),

Oldendorf/Luhe, Germany teria which cleave or demethylate dimethylsulfoniopropionate in the Caribbean Sea. Mar Ecol Prog Ser 89:293-296

Wolfe GV, Steinke M (1996) Grazing-activated production of dimethyl sulfide (DMS) by two clones of Emiliania huxleyi. Limnol Oceanogr 41:1151-1160

Wolfe GV, Sherr EB, Sherr BF (1994) Release and consumption of DMSP from Emiliania huxleyi during grazing by Oxyrrhis marina. Mar Ecol Prog Ser 111:111-119

Zeyer J, Eicher P, Wakeham SG, Schwarzenbach RP (1987) Oxidation of dimethyl sulfide to dimethyl sulfoxide by phototrophic purple bacteria. Appl Environ Microbiol 53: 2026-2032

Submitted: March 6, 2000; Accepted: May 23, 2000

Proofs received from author(s): September 28, 2000 